\title{
Calcium Release-activated Channels Inhibitor RP4010
}

National Cancer Institute

\section{Source}

National Cancer Institute. Calcium Release-activated Channels Inhibitor RP4010. NCI

Thesaurus. Code C136828.

A calcium $(\mathrm{Ca} 2+)$ release-activated channel (CRAC) inhibitor, with potential antineoplastic activity. Upon administration, RP4010 binds to and inhibits CRACs, thereby preventing the transport of extracellular $\mathrm{Ca} 2+$ into the cell and inhibiting the subsequent activation of Ca2+-mediated signaling and transcription of targ et genes. CRACs, specialized plasma membrane $\mathrm{Ca} 2+$ ion channels composed of the plasma membrane based Orai channels and the endoplasmic reticulum (ER) stromal interaction molecules (STIMs), play key roles in calcium homeostasis and are over-activated in a number of cancer cell types. Aberrant activation of CRACs leads to increased cancer cell proliferation. 